\title{
PENEGAKAN HUKUM DALAM PROSES PENAHANAN ORANG
}

Oleh :

Nunuk Sulisrudatin, SH, MSi

\begin{abstract}
:
Krisis ekonomi yang diikuti oleh krisis sosial dan krisis mental berkepanjangan, ternyata telah menjadi salah satu pemicu meningkatnya angka kejahatan dengan bentuk yang bervariasi dari satu kota dan kota lainnya. Maka pada gilirannya tempat- tempat penahan menjadi penuh dan melebhi kapasitas. Berbagai permasalahan yang menimpa Institusi Pemasyarakatan termasuk didalamnya institusi Rumah Tahanan Negara pada kenyataannya merupakan musibah Nasional, yang bisa membuat masyarakat menjadi resah dan merasa tidak aman, atau membuat masyarakat tidak mempercayai lagi kinerja petugas Pemasyarakatan dalam hal pengamanan wilayah kerja mereka. Oleh karena itu sudah selayaknya Institusi ini betul-betul mendapat perhatian khusus, mengingat kualitas dan kuantitas kriminal meningkat sejalan dengan kemajuan era globalisasi masa kini.
\end{abstract}

\section{PENDAHULUAN}

Usaha - usaha untuk membenahi dunia kepenjaraan ( prison) di Indonesia pada dasarnya tidak pernah berhenti, namun masih sangat sedikit orang yang peduli dengan permasalahan ini. Namun begitu sejalan dengan penghargaan orang terhadap Hak Asasi Manusia, maka permasalahan yang berkaitan dengan orang- orang yang sedang mengalami situasi penahanan akan menjadi suatu permaslahan yang harus diperhatikan.
Permasalahan - permasalahan yang menimpa Institusi Pemasyarakatan termasuk didalamnya institusi Rumah Tahanan Negara pada kenyataannya merupakan musibah Nasional, yang bisa membuat masyarakat menjadi resah dan merasa tidak aman, atau membuat masyarakat tidak mempercayai lagi kinerja petugas Pemasyarakatan dalam hal pengamanan wilayah kerja mereka. Oleh karena itu sudah selayaknya Institusi ini betul- betul mendapat perhatian khusus, mengingat kualitas dan kuantitas 
kriminal meningkat sejalan dengan kemajuan era globalisasi masa kini.

Dalam situasi dilandanya bangsa Indonesia dengan krisis ekonomi, kemudian diikuti oleh krisis sosial dan krisis mental yang berkepanjangan, maka hampir setiap hari orang menyaksikan pemberitaan di media massa tentang kejahatan yang sangat bervariasi dari satu kota dan kota lainnya. Maka pada gilirannya tempat- tempat penahan menjadi penuh dan melebhi kapasitas akibat dari meningkatnya angka kriminal dalam masyarakat, dan sejalan dengan itu aktivitas petugas kepolisian juga meningkat.

Memperhatikan tempat penahanan orangorang bermasalah dengan hukum pada dasarnya memperlihatkan kondisi yang sangat memprihatinkan, mengingat semakin banyaknya orang terjaring dengan berbagai macam kasus, pada kenyataannya tempat- tempat penahan baik pada tingkat penyidikan di Kepolisian maupun Rumah Tahanan Negara yang merupakan salah satu Unit Pelaksana Teknis Direktorat Jenderal Pemasyarakatan menunjukkan kondisi yang statis tanpa adanya perubahan baik dari kondisi bangunannya maupun kondisi pelayanannya. Selain itu belum banyak yang menuliskan mengenai tempat- tempat penahanan ini mengingat berbagai pertimbangan yang salah satu diantaranya adalah bahwa wilayah ini pada dasarnya belum menjadi wilayah pembahasan bidang Pemasyarakatan.

Dalam Literatur Pemasyarakatan Rumah Tahanan Negara selanjutnya disebut sebagai RUTAN, adalah merupakan Unit Pelaksana Teknis tempat tersangka atau terdakwa ditahan selama proses penyidikan, penuntutan dan pemeriksaan disidang Pengadilan. Selanjutnya yang dimaksudkan dengan Pembinaan dan Pola Pembinaan Tahanan adalah menyangkut pada Pelayanan Tahanan yaitu segala kegiatan yang dilaksankan dari mulai Penerimaan tahanan sampai dengan tahap pengeluaran tahanan. ${ }^{1}$

Pada dasarnya Rutan mrupakan wilayah yang sangat rentan terhadap pelanggaran hak asasi manusia, mengingat status orang yang ditahan masih harus diterapkan asas "Praduga Tidak Bersalah". Namun demikian sebagai salah satu Unit Pelaksana Teknis Pemasyarakatan Rumah- Rumah Tahanan Negara tetap memberlakukan peraturan sesuai Prosedur Tetap yang telah dibentuk dan dijadikan pedoman pelaksanaan tugas bagi petugas yang melaksanakan tugas dilapangan.

Mengingat perubahan dalam masyarakat yang dibarengi dengan meningkatnya kualitas dan kuantitas para pelaku kriminal, sedangkan dilain pihak sistem penanganan para Kriminal statis tanpa perubahan yang berarti. Untuk ini menurut Penulis diperlukan suatu tekat dan kemauan untuk merubah dan mengadakan perbaikan- perbaikan strategis terutama yang menyangkut Hak Asasi Manusia dalam Institusi ini.

\section{MASALAH PENAHANAN PRA- SIDANG}

Tokoh yang pernah membahas masalah Penahanan adalah E.H Sutherland dalam sebuah artikelnya yang berjudul "Detention Before Trial". Dalam artikel ini Sutherland telah membicarakan banyak hal terutama yang berkaitan dengan aspek- aspek negatif dari Penahanan sebelum proses

\footnotetext{
${ }^{1}$ Departemen Kehakiman RI. Pola Pembinaan Narapidana dan Tahanan; I; 1990.
} 
Sidang. (Sutheraland E.H., Principles of Criminology, Copyright 1960:356). Berkaitan dengan hal tersebut Perserikatan Bangsa Bangsa. juga memberikan Pedoman mengenai Standar- standar Internasional yang berhubungan dengan penahanan Pra- Sidang yaitu Norma- norma Internasional bagi perlindungan orangorang yang dituduh melakukan kejahatan atau mereka yang dirampas kebebasannya oleh Pemerintah.

Walaupun telah ada usaha Perserikatan Bangsa-Bangsa sehubungan dengan penahanan Pra- Sidang, tahanan-tahanan pra- sidang dibanyak negara mengalami kondisi penahanan terburuk dalam sistem penjara yang ada. Fasilitas penahanan sering terlalu padat, kuno, tidak sehat dan tidak layak sebagai habitat manusia.

Efek negatif dari penahanan Pra- Sidang antara lain menyebabkan ketegangan yang hebat bagi orang- orang yang tidak tahu pasti tentang masa depannya karena waktu menunggu proses persidangan, dan sewaktu- waktu mereka merasa terancam keamanannya oleh lingkungan dan perlakuan yang tidak manusiawi dari petugas atau sesama tahanan. Bahwa keterkaitan satu masalah dengan masalah lainnya akhirnya membuat permasalahan yang berkaitan dengan Hak Asasi Manusia terabaikan.

\section{OPERASIONAL PELAYANAN TAHANAN PRA-SIDANG}

Kovenan tentang Hak- hak Sipil dan Politik, Pasal 14 ( 2 ) mengatakan: "Setiap orang yang dituntut atas tindak pidana berhak untuk dianggap tidak bersalah sampai terbukti bersalah menurut hukum". Demikian juga Peraturan Standar Minimum, Peraturan 84 (2) mengatakan bahwa: "Tahanan yang belum dijatuhi hukuman dianggap tidak bersalah dan harus diperlakukan demikian".

Arah strategis dari pasal tersebut adalah untuk dapat menunjukkan realisasi "Praduga Tak Bersalah" kepada mereka yang sedang dalam prases penahanan. Hal ini merupakan prinsip umum bahwa setiap orang yang dituduh melakukan tindak pidana berhak untuk dianggap tidak bersalah. Dengan begitu perlakuan pun harus dibedakan dengan mereka yang telah berstatus Narapidana. Hal ini diprioritaskan sebagai langkah awal bagi semua standar dibidang Penahanan PraSidang, dan orang- orang yang belum dihukum atas kejahatan yang dituduhkan. Satu aspek yang perlu mendapat perhatian berkaitan dengan perlakuan kepada orang yang masih dalam status penahanan adalah bila mereka ditempatkan pada kelas yang sama dengan Narapidana dan diberlakukan peraturan disiplin yang sama.

Kovenan tentang Hak- hak Sipil dan Politik Pasal 10 (2) mengatakan :

a Kecuali dalam hal- hal tertentu, tersangka harus dipisahkan dari Narapidana dan harus mendapat perlakuan yang berbeda sesuai dengan status mereka sebagai orang yang belum dihukum;

b Tersangka anak- anak harus dipisahkan dari orang dewasa dan harus secepat mungkin diputus perkaranya.

Peraturan Standar Minimum (Peraturan 8) menjabarkan antar lain: "Narapidana dengan kategori yang berbeda harus ditempatkan dalam lembaga atau bagian lembaga yang berbeda, dengan memperhatikan Jenis kelamin, Umur, 
Catatan kriminal, Alasan hukum penahanan mereka dan Perlunya perlakuan terhadap mereka. Oleh karena itu, Pria dan wanita harus ditempatkan dalam tempat yang terpisah, Tahanan yang belum diadili harus dipisahkan dari Narapidana, Narapidana muda harus dipisahkan dengan Narapidana dewasa.

Kendala yang sedang dihadapi oleh pihak Pemasyarakatan berkaitan dengan Hak Asasi Manusia saat ini adalah belum diberlakukannya "Pemisahan Kelas- kelas Tahanan" sebagaimana yang diatur dalam Pedoman mengenai StandarStandar Internasional yang berhubungan dengan Penahanan Pra- Sidang dari PBB. tersebut, dan menurut penulis hal ini merupakan salah satu pemicu terjadinya berbagai permasalahan dalam Institusi ini.

Permasalahan lain yang dapat diungkap adalah bila meninjau masalah Perawatan Medis bagi Tahanan. Peraturan Standar Minimum, Peraturan 22 tentang Perawatan Medis menyatakan antara lain: "Dengan belum diberlakukannya beberapa Standar Minimum dari Pedoman mengenai Standar- Satandar Internasional yang berhubungan dengan Penahanan Pra- Sidang, maka Institusi Pemasyarakatan akan menemui berbagai permasalahan yang berkaitan dengan Hak Asasi Manusia.

Permasalahan berat lain yang dihadapi oleh institusi ini adalah, sejak negara kita memberlakukan Undang - undang No. 5 tahun 1997 tentang Psikotropika, dan Undang - undang No 22 tahun 1997 tentang Narkotika. Dalam permasalahan ini para pembuat Undang- undang seakan- akan belum memperhitungkan akibat dari pemberlakuan undangundang itu, oleh karena pada kenyataannya Unit Pemasyarakatan harus menampung mereka yang terjaring undang- undang tersebut. Kondisi ini pada kenyataan membuat isi LP. atau Rutan terutama LP. dan Rutan yang berada dikota- kota besar menjadi padat, dan akibat selanjutnya adalah tempat penampungan para tahanan menjadi tidak manusiawi.

Bahwa mereka yang terjaring undangundang Narkotika dan Psikotropika ini terdiri dari Bandar, Pengedar, Pemakai, dan juga mereka yang sudah menjadi Pecandu narkotika atau "Korban Narkoba". Problem tidak adanya "Pemisahan kelas" dari tahanan yang bermasalah dengan "Narkoba" ternyata berdampak sangat luas pada institusi Pemasyarakatan, terutama yang menyangkut tanggung jawab secara kemanusiaan pada para "Korban Narkoba" yang secara teknis tidak teratasi oleh para petugas Pemasyarakatan.

Hal itu terjadi karena pada kenyataanya "Korban" itu memerlukan perawatan khusus. ( Dalam istilah ini dinamakan "Sakau" yang bisa mengakibatkan kematian), sedangkan petugas Pemasyarakatan belum ada yang terlatih untuk tehnik ini. Permasalahan ini tentu sangat memprihatinkan dan perlu segera mendapat perhatian dari Lembaga Hak Asasi Manusia.

Berikut penulis mencoba menguraikan siklus permasalahan dalam Institusi Pemasyarakatan yang berkaitan dengan Hak Asasi Manusia sebagai berikut :

1. Pihak Pemasyarakatan kesulitan mengadakan pemisahan kelas- kelas dikarenakan terbatasnya fasilitas, menyangkut gedung, dan anggaran biaya. 
2. Akibat tidak ada pemisahan kelaskelas maka pihak Pemasyarakatan terbentur pada pemasalahanpermasalahan antara lain :

a Pelanggaran HAM terhadap orang berstatus tahanan karena pemberlakuan yang sama antara tahanan dan Narapidana. (Asas Praduga Tak Bersalah tidak beralaku ).

b Terjadi transaksi jual beli jasa antara petugas dan para tahanan yang menginginkan fasilitas yang lebih manusiawi.

c Selanjutnya bersamaan dengan itu muncul Diskriminasi terhadap penghuni LP dan Rutan.

d Akibat diskriminasi membuat keadaan potensi untuk timbul perkelahian, tawuran, dan kekacauan atau kerusuhan.

e Maraknya peredaran Narkoba dalam LP dan Rutan sangat mungkin dikarenakan bercampur aduknya penempatan berbagai jenis Kriminal, termasuk didalamnya adalah mereka yang menjadi Bandar, Pengedar, dan Pemakai narkoba.

f Seringnya terjadi kematian tahanan akibat "Sakau"

g Tersangkutnya petugas dalam permasalahan jaringan peredaran narkoba di dalamRutan, maupun di luar Rutan

Demikian menurut penulis sudah saatnya Lembaga Hak Asasi Manusia turut memikirkan pemecahan masalah dalam
Institusi Pemasyarakatan yang sering bermasalah akhir- akhir ini, tentu dengan suatu tekat dan kemauan untuk kebaikan.

\section{PENUTUP}

Kondisi Terkini, pelaksanaan tugas pada Unit Pelaksana Teknis / UPT Pemasyarakatan belum menunjukkan kinerja yang optimal. Hal ini tercermin dari pelayanan umum menempatkan Pemasyarakatan sebagai salah satu institusi yang nilai layanan publiknya berada pada level yang rendah. Rendahnya indeks pelayanan publik Pemasyarakatan ini tidak dapat dilepaskan dari beberapa aspek, salah satunya adalah aspek manajemen organisasi. Manajemen organisasi pada Kementerian Hukum dan HAM (khususnya UPT Pemasyarakatan) tidak mencerminkan adanya upaya untuk terwujudnya efisiensi dan efektifitas.

Dalam administrasi birokrasi masa kini, pada dasarnya kepala UPT Pemasyarakatan bertanggungjawab secara administratif kepada Kepala Kantor Wilayah (Kakanwil) Kementerian Hukum dan HAM sedangkan Kakanwil bertanggungjawab langsung kepada Menteri. Posisi Direktorat Jenderal Pemasyarakatan berada di bawah organisasi kementerian dan bertanggung jawab kepada Menteri. Sedangkan Kepala Divisi Pemasyarakatan (Kadiv Pas), bertanggungjawab kepada Kakanwil. Dengan demikian, tidak ada garis struktural secara langsung antara Direktur Jenderal Pemasyarakatan, Kepala Divisi Pemasyarakatan, dan Kepala UPT Pemasyarakatan.

Di sisi ini terlihat dualisme tata hubungan dalam tatanan struktural dan teknis organisasi, di mana secara struktur organisasi yang sama-sama menjalankan 
fungsi pemasyarakatan itu tunduk pada hierarki organisasi strukturalnya masingmasing meskipun secara teknis organisasiorganisasi tersebut saling berhubungan. Bidang struktural yang menitikberatkan pada dukungan fasilitatif, kepegawaian dan anggaran kepada bidang teknis yang menjalankan fungsi - fungsi Pemasyarakatan sejatinya berada dalam satu hierarki manajemen terpadu.

Dalam banyak hal, tata hubungan tersebut tidak terselenggara dalam system organisasi Pemasyarakatan di Kementerian Hukum dan HAM. Pada akhirnya sistem ini menjadi faktor penyebab timbulnya permasalahan dalam keberhasilan kinerja sistem pemasyarakatan secara keseluruhan menyangkut unit pelaksana teknis.

\section{DAFTAR BACAAN}

1. Edwin H. Sutherland, Principles Of Criminology, Sixth Edition, J.B. Lippincott Company, Copyright 1960.

2. Hadi Setia Tunggal SH. Deklarasi Universal Tentang Hak- Hak Asasi Manusia, Harvarindo, 2000.

3. Harkristuti Harkrisnowo, SH. Christianus H. Panjaitan, Pedoman mengenai Standar - standar Internasional yang berhubungan dengan Penahanan Pra- Sidang, Professional Training Series No. 3 .

4. Drs. M. Wresniwiro, Kollonel Polisi. Masalah Narkotika, Psikotropika dan Obat - obat Berbahaya, Mitr BintibMas, 1999. 